\title{
EVALUATION OF MICRO-ORGANISMS FOR BIOCONTROL OF GREY MOULD ON LETTUCE
}

\author{
S. CARD ${ }^{1}$, M.V. JASPERS ${ }^{1}$, M. WALTER ${ }^{2}$ and A. STEWART ${ }^{1}$
}

${ }^{1}$ Soil, Plant and Ecological Sciences Division, PO Box 84, Lincoln University, Canterbury

${ }^{2}$ The Horticulture and Food Research Institute of New Zealand Ltd., PO Box 51, Lincoln

Corresponding author: cards@lincoln.ac.nz

\begin{abstract}
A range of micro-organisms, including saprophytic yeasts, bacteria and fungi, were evaluated for control of Botrytis grey mould on whole lettuce plants. In a controlled environment $\left(18-22^{\circ} \mathrm{C}, 85-90 \%\right.$ relative humidity and $12 \mathrm{~h}$ photoperiod), lettuce leaves were spray inoculated with antagonists $\left(10^{7}\right.$ fungal spores $/$ cells $/ \mathrm{ml}$ or $10^{8}$ bacterial cells $\left./ \mathrm{ml}\right)$, allowed to dry and challenged by spray inoculation with the pathogen $\left(10^{6} \mathrm{spores} / \mathrm{ml}\right)$. After 7 days, the mean Botrytis lesion areas were assessed. Four fluorescent Pseudomonas spp. (isolates LC8, PF13, PF14 and PF15) significantly reduced lesion areas by an average of $79 \%$ on whole lettuce plants in two experiments. An Ulocladium sp. (U13) significantly reduced lesion areas by $94 \%$ in one of two experiments.

Keywords: Botrytis cinerea, Epiccocum, Ulocladium, Pseudomonas, antagonist.
\end{abstract}

\section{INTRODUCTION}

The causal agent of grey mould, Botrytis cinerea Pers., is a ubiquitous necrotrophic pathogen and can infect almost every plant part on a wide range of plants worldwide (Rosslenbroich \& Stuebler 2000). In New Zealand, the fungus can cause significant economic losses on grape, strawberry, tomato, lettuce and kiwifruit. Current control relies heavily on the use of chemical fungicides but due to the pathogen's highly variable heterokaryotic nature, there is a high risk of resistance developing (Fletcher 1984). Fungicides used to control the pathogen are rapidly losing their efficacy since resistant strains are now widespread throughout the world, including New Zealand. This coupled with the current public concern over pesticide residues on foodstuffs and the expanding demand for organically grown vegetables and fruits, highlights the need for an alternative to chemical control. Biological control of this ubiquitous fungal pathogen has been shown to be effective in many crops (Elad et al. 1996) and can offer an attractive alternative to chemical control.

In vitro biological control screens are generally poor predictors of the performance of micro-organisms in the field (Andrews 1992) and, therefore, the objective of this study was to develop a standardised, efficient screen that would evaluate the biocontrol potential of micro-organisms in the whole plant environment. Lettuce was chosen as the model system since $B$. cinerea can cause significant loss to the crop both pre and post harvest.

\section{Test micro-organisms}

\section{METHODS}

There were two separate trials of different antagonistic micro-organisms. Each trial consisted of two identical experiments, the second experiment being carried out ten days after the first one. Each experiment was a randomised complete block design, with 14 treatments in Trial 1 and 10 treatments in Trial 2. All treatments were replicated four 
times. In all experiments the pathogen only control was sprayed with aqueous Tween 80 solution (1 drop per $1000 \mathrm{ml}$ ) instead of antagonist or fungicide.

In Trial 1 seven fungal antagonists and three bacterial antagonists with known biocontrol activity against other fungal pathogens were selected from the Lincoln University culture collection. These were Cladosporium spp. (ER3 and YNA) and Pseudomonas marginalis (GA8-PS4) from Camellia japonica flowers (R. van Toor, unpubl. data), Trichoderma harzianum (C52) and T. longipile (6sr4) from lettuce (Rabeendran et al. 1998), Ulocladium spp. (U13 and U16) and Epicoccum sp. (E21) from grape leaf (Stewart et al. 1998), Bacillus subtilis (PT69) and Paenibacillus polymyxa (18-25) from soil (Wakelin 2001). The performance of the selected microorganisms was compared to two commercial biocontrol products and a chemical fungicide, recommended for control of Botrytis. The commercial product Trichodex (provided by Makhteshim Agan Chemical works Ltd., Be'er Sheva, Israel), containing over $5 \times 10^{8}$ Colony Forming Units (CFU)/g of T. harzianum T39, was applied at the recommended rate of $4 \mathrm{~g} /$ litre. The commercial product Prestop (provided by Kemira Agro Oy, Porkkalankatu, Helsinki, Finland), containing over $10^{7} \mathrm{CFU} / \mathrm{g}$ of Gliocladium catenulatum, was applied at the recommended rate of $10 \mathrm{~g} /$ litre. The fungicide iprodione was applied at the recommended rate of $0.25 \mathrm{~g}$ ai/litre (Rovral FLO $15 \mathrm{ml} /$ litre).

The second trial (Trial 2) used one unidentified white yeast (PK10), three unidentified pink yeasts (Y44, Y46 and Y48), three unidentified fluorescent Pseudomonas spp. (PF13, PF14 and PF15) isolated from strawberry fruit and P. fluorescens (LC8) isolated from C. japonica flowers (R. van Toor, unpubl. data).

\section{Inoculum production}

Botrytis cinerea was isolated from an infected commercial lettuce crop (Marshlands, Christchurch) and maintained on potato dextrose agar (PDA, Oxoid) at $20^{\circ} \mathrm{C}$. Inoculum was produced in the same way as the antagonistic fungi.

Filamentous fungi, yeasts and bacteria were stored on PDA, malt extract agar (MEA, Difco) and nutrient agar (NA, Difco) respectively at $-4^{\circ} \mathrm{C}$. Filamentous fungi were cultured on PDA at $20^{\circ} \mathrm{C}$ for 10-29 days and yeasts for 3 days on MEA plates. Sporulation of the fungi was initiated by cultivating under fluorescent light with a $12 \mathrm{~h}$ photoperiod regime. All fungal spore suspensions were prepared by flooding individual cultures with $10 \mathrm{ml}$ aqueous Tween 80 solution (1 drop in $1000 \mathrm{ml}$ sterile water) and scraping gently with a sterile loop. The resulting crude suspension was filtered through a layer of Miracloth (Calbiochem) to remove mycelial fragments. Bacteria were cultured in $50 \mathrm{ml}$ of nutrient broth (Difco) in $250 \mathrm{ml}$ Erlenmeyer flasks at room temperature on an orbital shaker at $160 \mathrm{rpm}$ for $24 \mathrm{~h}$. Cells were collected by centrifugation for $10 \mathrm{~min}$ at $1000 \mathrm{x} \mathrm{g}$ and re-suspended in aqueous Tween- 80 solution ( 1 drop in $1000 \mathrm{ml}$ sterile water). Inoculum concentration was estimated using a haemocytometer and adjusted to $1 \times 10^{6}$ conidia $/ \mathrm{ml}$ for $B$. cinerea, $1 \times 10^{7}$ spores $/ \mathrm{ml}$ for other fungi and $1 \times 10^{8}$ cells $/ \mathrm{ml}$ for bacteria.

\section{Treatment and assessment of plants}

Plastic pots ( 2 litre) were filled with potting mix consisting of $80 \%$ composted pine bark, 20\% WAP5 washed crusher dust and Osmocote Plus fertiliser at $5 \mathrm{~kg} / \mathrm{m}^{2}$. Lettuce seeds of the Marksman type (Yates, Australia), a variety of iceberg lettuce partially resistant to powdery mildew, were planted four to a pot with a coverage of no more than $5 \mathrm{~mm}$ potting mix. They were grown in a glasshouse with temperatures of $15-25^{\circ} \mathrm{C}$ (monitored using a Tinytag temperature data logger), with irrigation as needed, but without additional lighting. After three weeks, they were thinned to one per pot and transferred to a controlled environment $\left(18-22^{\circ} \mathrm{C}, 85-90 \%\right.$ relative humidity and $12 \mathrm{~h}$ photoperiod) for 3 weeks to adapt to these conditions.

At the start of the experiments, small wounds $(3 \mathrm{~mm}$ diameter) were made on the centre lower section of three medium sized leaves per lettuce plant (1 wound per leaf) using an electric powered soldering iron. Freshly wounded leaves were sprayed with a suspension of antagonist, aqueous Tween 80 solution (pathogen only control) or fungicide 
till near run off (leaves were uniformly covered) using a handheld sprayer. After $10 \mathrm{~min}$, a suspension of $B$. cinerea was applied to each plant, 1 spray per wound, using the hand held sprayer. Disease progress was assessed after 7 days by measuring the length and width of disease lesions ( $\mathrm{mm}$ ) spreading from the wound site using a digital calliper. Total lesion area was calculated and analysis of variance (ANOVA) was used to determine differences between means. Fishers Least Significant Difference (LSD) test was used to rank treatments in order of effectiveness.

\section{Trial 1}

\section{RESULTS}

In experiment 1 , iprodione and Ulocladium (U13) significantly reduced lesion development compared to the pathogen-only control $(\mathrm{P}<0.05)$. These treatments were not different from each other ( $\mathrm{P}>0.05)$. Percentage reduction in lesion area was $95 \%$, 94\% and 78\% respectively (Table 1). Other isolates, namely P. polymyxa (18-25), Ulocladium (U16), Trichoderma spp. (C52 and 6sr4) and the commercial product Prestop gave percentage reductions in lesion area ranging from $56 \%$ to $74 \%$ but these were not significantly different from the pathogen control (Table 1). In experiment 2 , no treatment gave a significant reduction in lesion development compared to the pathogen-only control although Epicoccum (E21) and Ulocladium (U13) again gave the greatest reduction in lesion area of $78 \%$ and $41 \%$ respectively (Table 1).

TABLE 1: The size of $B$. cinerea lesions $\left(\mathrm{mm}^{2}\right)$ on lettuce after treatment with various micro-organisms. Results are presented for both experiments in Trial 1.

\begin{tabular}{lrr}
\hline Treatment & Experiment 1 & Experiment 2 \\
\hline Pathogen control & $1990 \mathrm{a}^{1}$ & $514 \mathrm{a}^{1}$ \\
Pseudomonas marginalis (Ga8-PS4) & $1420 \mathrm{a}$ & $424 \mathrm{a}$ \\
Paenibacillus polymyxa(18-25) & $520 \mathrm{a}$ & $750 \mathrm{a}$ \\
B. subtilis (PT69) & $1500 \mathrm{a}$ & $873 \mathrm{a}$ \\
Epicoccum (E21) & $441 \mathrm{a}$ & $115 \mathrm{a}$ \\
Ulocladium (U13) & $122 \mathrm{~b}$ & $303 \mathrm{a}$ \\
Ulocladium (U16) & $665 \mathrm{a}$ & $387 \mathrm{a}$ \\
T. harzianum (C52) & $875 \mathrm{a}$ & $620 \mathrm{a}$ \\
T. longipile (6sr4) & $692 \mathrm{a}$ & $1090 \mathrm{a}$ \\
Cladosporium (ER3) & $761 \mathrm{a}$ & $1308 \mathrm{a}$ \\
Cladosporium (YNA) & $1340 \mathrm{a}$ & $855 \mathrm{a}$ \\
Trichodex & $1180 \mathrm{a}$ & $1070 \mathrm{a}$ \\
Prestop & $824 \mathrm{a}$ & $459 \mathrm{a}$ \\
Iprodione & $93 \mathrm{~b}$ & $498 \mathrm{a}$
\end{tabular}

${ }^{1}$ Means in a column followed by the same letter are not significantly different at $\mathrm{P}<0.05$ according to Fishers Least Significance Difference test.

\section{Trial 2}

Four isolates of fluorescent Pseudomonas (LC8, PF13, PF14 and PF15) gave a significant reduction in Botrytis lesion area compared to the pathogen control in both experiments. Lesion areas were reduced by $60 \%$ to $84 \%$ in experiment 1 and by $62 \%$ to $96 \%$ in experiment 2 (Table 2). Isolate PF13 showed greatest suppression with lesion areas ranging from 159 to $513 \mathrm{~mm}^{2}$ which was equivalent to a lesion area reduction of $76 \%$ and $96 \%$, respectively compared to the pathogen control (Table 2). 
TABLE 2: The size of $B$. cinerea lesions $\left(\mathrm{mm}^{2}\right)$ on lettuce after treatment with various micro-organisms. Results are presented for both experiments in Trial 2.

\begin{tabular}{lrr}
\hline Treatment & Experiment 1 & Experiment 2 \\
\hline Pathogen control & $2120 \mathrm{a}^{1}$ & $3810 \mathrm{a}$ \\
Unidentified yeast (PK10) & $1110 \mathrm{a}$ & $4010 \mathrm{a}$ \\
Unidentified yeast (Y44) & $1560 \mathrm{a}$ & $2830 \mathrm{a}$ \\
Unidentified yeast (Y46) & $1720 \mathrm{a}$ & $2620 \mathrm{a}$ \\
Unidentified yeast (Y48) & $1740 \mathrm{a}$ & $3890 \mathrm{a}$ \\
T. harzianum (C52) & $1430 \mathrm{a}$ & $3990 \mathrm{a}$ \\
P. fluorescens (LC8) & $601 \mathrm{~b}$ & $371 \mathrm{~b}$ \\
Fluorescent Pseudomonas (PF13) & $512 \mathrm{~b}$ & $159 \mathrm{~b}$ \\
Fluorescent Pseudomonas (PF14) & $349 \mathrm{~b}$ & $222 \mathrm{~b}$ \\
Fluorescent Pseudomonas (PF15) & $845 \mathrm{~b}$ &
\end{tabular}

${ }^{1}$ Means in a column followed by the same letter are not significantly different at $\mathrm{P}<0.05$ according to Fishers Least Significance Difference test.

\section{DISCUSSION AND CONCLUSIONS}

This study evaluated 18 micro-organisms, two commercial biocontrol products and a fungicide for the suppression of $B$. cinerea lesions on whole lettuce plants in a controlled environment. Four fluorescent Pseudomonas spp. significantly reduced Botrytis lesion development compared to the pathogen only control. Fluorescent Pseudomonas spp. have been shown to antagonise a wide range of fungal and bacterial pathogens on a wide range of plants. For example, an isolate marketed as BlightBan has been commercialised for the control of bacterial pathogens on aerial plant surfaces (Wilson 1997). Another P. fluorescens isolate (PB92BB10E) was found to suppress $B$. cinerea on whole petunia plants by an average of $77 \%$ across seven different trials (Gould et al. 1996). Swadling \& Jeffries (1996) identified a strain of $P$. fluorescens that was equally or more effective than the fungicide dichlofluanid for controlling grey mould in a strawberry field trial. Past research has shown that antagonistic activity of fluorescent Pseudomonas spp. is based on fungistatic and/or germicidal activity (Swadling \& Jeffries 1998; Gould et al. 1996).

The Epicoccum sp. (E21) reduced lesion areas by an average of $78 \%$ in both experiments compared to the pathogen only control, although this difference was not statistically significant. An Epicoccum sp. has previously been shown to suppress B. cinerea on bean (Hannusch \& Boland 1996). It was found that biocontrol efficacy was independent of the atmospheric environment when evaluated at temperatures ranging from $20-28^{\circ} \mathrm{C}$ and relative humidities ranging from $90-100 \%$. Under these conditions, the isolate reduced grey mould by $100 \%$. Mechanisms of action were attributed to competition for nutrients or antibiosis (Hannusch \& Boland 1996).

Ulocladium (U13) reduced lesion area significantly in experiment 1 but not experiment 2 of Trial 1. An Ulocladium atrum isolate suppressed the sporulation of $B$. cinerea on strawberry, onion, cyclamen and geranium (Kohl \& Fokkema 1998) by competitively excluding the pathogen from colonising senescent tissue. Both the Epicoccum and Ulocladium isolates used in this study had already been shown to suppress $B$. cinerea infection and sporulation on sterilised grape rachii (Fowler et al. 1999). The species identities of the most successful isolates from this study are not yet known.

In experiment 1 of Trial 2, the results were confounded by an unusually low infection level in the pathogen control. This could have been due to the $B$. cinerea isolate losing its aggressiveness after frequent propagation onto PDA. Prior to the second experiment, the pathogen was re-isolated back from diseased lettuce leaves in order to maintain its aggressiveness. 
It is concluded that Epicoccum (E21), Ulocladium (U13) and the four fluorescent Pseudomonas spp (LC8, PF13, PF14 and PF15) offer the most potential for the antagonism of $B$. cinerea. These isolates will now be assessed for the control of $B$. cinerea on whole plants in a large-scale field trial. Research will also aim to identify the mode of action of the most successful isolates as this information may help to optimise their biocontrol efficiency in the field.

\section{ACKNOWLEDGEMENTS}

We would like to thank the New Zealand Vegetable and Potato Grower's Federation for financial support.

\section{REFERENCES}

Andrews, J.H. 1992: Biological control in the phyllosphere. Ann. Rev. Phytopath. 30: 603-635

Elad, Y; Malathrakis, N.E; Dik, A.J. 1996: Biological control of Botrytis-incited diseases and powdery mildews in greenhouse crops. Crop Prot. 15: 229-240.

Fletcher, J.T. 1984: Diseases of Greenhouse Plants. Longman. London.

Fowler, S.R; Jaspers, M.V; Walter, M; Stewart, A. 1999: Suppression of overwintering Botrytis cinerea inoculum on grape rachii using antagonistic fungi. Proc. 52nd N.Z. Plant Prot. Conf:: 141-147.

Gould, A.B; Kobayashi, D.Y; Bergen, M.S. 1996: Identification of bacteria for biological control of Botrytis cinerea on petunia using a petal disk assay. Plant Disease 80:1029-1033

Hannusch, D.J; Boland, G.J. 1996: Interactions of air temperature, relative humidity and biological control agents on grey mould of bean. European J. Plant Path. 102: $133-142$

Kohl, J; Fokkema, N, J. 1998: Biological control of Botrytis cinerea by suppression of sporulation. Brighton Crop Prot. Conf. - Pests \& Diseases 7C:681-686.

Rabeendran N; Jones, E.E; Stewart A. 1998: Isolation and in vitro screening of soil fungi for biological control of Sclerotinia sclerotiorum. Proc. 51st N.Z. Plant Prot. Conf.: 102-106.

Rosslenbroich H; Stuebler, D. 2000: Botrytis cinerea - history of chemical control and novel fungicides for its management. Crop Prot. 19: 557-561.

Stewart, A; Antonov, A; Trought, M; Walter, M. 1998: Biological control of Botrytis bunch rot of grapes using naturally occurring fungal antagonists. Proc. 7th Int. Cong. Plant Path. Abstract p73.

Swadling, I.R; Jeffries, P. 1996: Isolation of microbial antagonists for biocontrol of grey mould disease of strawberries. Biocontrol, Sci. Technol. 6: 125-136.

Swadling, I.R; Jeffries, P. 1998: Antagonistic properties of two bacterial biocontrol agents of grey mould disease. Biocontrol, Sci. Technol. 8: 439-448.

Wakelin, S.A. 2001: Biological control of Aphanomyces euteiches root rot of pea with spore-forming bacteria. PhD Thesis. Lincoln University, Canterbury.

Wilson, M. 1997: Biocontrol of aerial plant diseases in agriculture and horticulture: current approaches and future prospects. J. Industrial Microbiol. Biotech. 19: 188191. 